\title{
Persistence of Dothistroma septosporum on Abscised Pine Needles and its Implications for Disease Management
}

Martin Mullett, Forest Research, Alice Holt Lodge, Farnham, Surrey, GU10 4LH, UK; Andy Peace, Forest Research, Northern Research Station, Roslin, Midlothian, EH25 9SY, UK; and Anna Brown, Forestry Commission, Silvan House, 231 Corstorphine Road, Edinburgh, EH12 7AT, UK

\begin{abstract}
Mullett, M., Peace, A., and Brown, A. 2016. Persistence of Dothistroma septosporum on abscised pine needles and its implications for disease management. Plant Dis. 100:1271-1277.

Dothistroma septosporum is a serious foliar pathogen of pines in Britain. To determine the contribution of spores produced on abscised needles to the D. septosporum inoculum load in a forest environment, survival of the fungus was investigated in commercially grown plantations of Corsican pine (Pinus nigra subsp. laricio) in southern England. The fungus persisted for longer in abscised needles retained in the canopy compared with needles on the litter layer of the forest floor. High relative humidity had a significant negative effect on persistence in the canopy needles, highlighting the effect of moisture on rates of microbial

decay. The median lethal time $50\left(\mathrm{LT}_{50}\right)$ of infective propagules from needles in the litter layer was 20 to 28 days, whereas for needles suspended in the canopy it was 34 to 48 days. Microsatellite markers revealed that the population of $D$. septosporum deemed persistent (i.e., recovered from abscised needles after exposure for 28 to 32 weeks) was similar to the general population of D. septosporum in the forest stand (i.e., isolates recovered from attached needles and after exposure for only 4 weeks). Overall, abscised needles with acervuli of $D$. septosporum contribute only moderately and for a limited time to inoculum levels of the pathogen in an infected forest stand.
\end{abstract}

Dothistroma needle blight (DNB) is a serious and economically important disease of pines that causes premature defoliation, decreased yield, and in extreme cases, tree death (Brown and Webber 2008). Although two fungal species, Dothistroma septosporum (Doroguine) Morelet (sexual stage Mycosphaerella pini) and D. pini Hulbary (sexual stage unknown) cause the disease, D. septosporum is the most widely distributed and the only DNB pathogen found in Great Britain. Over 80 species of Pinus are affected by the disease (Watt et al. 2009), but Corsican pine (Pinus nigra J.F. Arnold subsp. laricio (Poir.)) is one of the most susceptible (Gilmour 1967) and an important commercial forestry species in Britain (Brown and Webber 2008). Infection takes place primarily in the spring and early summer via rain-splash dispersed conidia, which form in acervuli on infected needles (Gibson 1972; Karadžić 1989; Mullett 2014; Peterson 1967, 1973; Rogerson 1953). Initial symptoms appear as chlorotic bands but quickly progress to brown necrotic bands, often associated with a brick-red discoloration, with black acervuli forming within the bands (Brown and Webber 2008). Symptoms may be seen by late autumn, but typically the most abundant and clearest symptoms appear the following spring, when acervuli are formed in the needles infected the previous year and produce conidia which infect the new current year's needles (Mullett 2014). Affected needles are predominantly cast in the summer (July), prior to the main shedding of older but uninfected needles in the fall, although infected needles can be cast at any time of year (Karadžić 1989; Mullett 2014). The cast needles contain many acervuli which produce large numbers of infective conidia and have the potential to be a major source of inoculum, particularly if they remain viable for long enough to take advantage of conditions conducive to infection.

Corresponding author: Martin Mullett,

E-mail: martin.mullett@ forestry.gsi.gov.uk

*The $\boldsymbol{e}$-Xtra logo stands for "electronic extra" and indicates that one supplementary table is included in the online edition.

Accepted for publication 10 February 2016.

http://dx.doi.org/10.1094/PDIS-11-15-1306-RE

(C) 2016 The American Phytopathological Society
Abscised leaves and plant debris are known to be significant sources of inoculum in a number of plant diseases. Ascospores of Venturia inaequalis produced on apple leaf litter initiate epidemics of apple scab (Gladieux et al. 2008; MacHardy 1996; Xu et al. 2012). Sanitation measures to remove or destroy the leaf litter in apple orchards can reduce the subsequent incidence of apple scab by up to 57\% (Holb 2006). Another example, ascochyta blight of pulse crops, is caused by a number of pathogens including Mycosphaerella pinodes and various Ascochyta spp., and the primary inoculum source is from infested plant residues from the previous season (Davidson and Kimber 2007). In fact, crop residues are considered the most important source of inoculum for various fungi causing ascochyta blight of faba bean, field pea, lentil, and bean crops in countries as diverse as Canada, Australia, and the United Kingdom (Bond and Pope 1980; Bretag et al. 2006; Carter and Moller 1961; Hawthorne et al. 2004; Morrall 1997). In a forestry environment, the main inoculum source of the pine needle pathogen Lophodermium seditiosum comes from fallen needles (Diwani and Millar 1990). Most needles infected with L. seditiosum are cast prematurely in early summer, with fruit bodies developing rapidly and producing spores that infect current years' needles a few months later in the late summer and autumn (Diwani and Millar 1990; Strouts and Winter 2000). D. septosporum also causes premature defoliation in the summer; however, fruit bodies of the pathogen are present, and spores disseminated, while the needles are still attached (Mullett 2014). Thus it is not known whether fallen needles infected with $D$. septosporum act as a source of inoculum in a similar manner to those of L. seditiosum and if so, how much they contribute to the total inoculum load in the stand.

When needles are shed prematurely, they either become lodged in the dense network of branches and hang suspended above the ground, or they land on the litter layer of the forest floor. These positions present different threats for infection, with spores from suspended needles a threat to both canopy needles and regeneration on the forest floor while spores from needles in the litter are predominantly a threat to regeneration or new plantings. The position of abscised needles will also present very different conditions for the needles and accompanying fungi both in terms of moisture and temperature, as well as the presence of competing saprophytic microfungi. For instance, needles caught in branches are exposed to drying breezes and are not in contact with the heavily colonized litter layer of the forest floor. 
Knowledge of how long D. septosporum propagules survive in abscised needles should help inform management decisions for infected stands. For example, the frequency or timing of thinning and pruning regimes could be altered if suspended needles in the canopy proved to be a significant source of inoculum. Thinned and pruned stands have fewer branches to trap falling needles and provide increased air flow, thereby reducing the likelihood of infection by promoting conditions less suitable for spore dispersal and infection. Knowledge of survival times of the fungus in the litter layer might also affect the length of time before replanting a site and has implications for nursery sanitation measures. Therefore, this study aimed to i) investigate whether abscised needles produce substantial quantities of inoculum compared with attached needles, ii) determine how long D. septosporum can survive in detached needles both when caught in the canopy and when part of the litter layer, iii) assess if weather conditions play a role in the longevity of the fungus in abscised needles, and iv) examine, using microsatellite analysis, whether any particular D. septosporum multilocus haplotypes are better suited to persisting in abscised needles.

\section{Materials and Methods}

Trial design. An infected stand of unthinned 19-year-old $P$. nigra subsp. laricio in the south of England (Abbotts Wood Compartment $68 \mathrm{C}$, planted $1992,51^{\circ} 09^{\prime} 32^{\prime \prime} \mathrm{N}, 0^{\circ} 50^{\prime} 14^{\prime \prime} \mathrm{W}$ ) was chosen for the experiment as it represented a typical closed-canopy stand where many needles are caught in the canopy on abscission. However, needles were too inaccessible for regular collection, so needles still attached to twigs and naturally infected with $D$. septosporum were collected from a nearby 9 -year-old stand of $P$. nigra subsp. laricio (Compartment 75B, planted 2002, 51 $09^{\prime} 09^{\prime \prime} \mathrm{N} \mathrm{0} 50^{\prime} 13^{\prime \prime} \mathrm{W}$ ), with a fruit body of the pathogen present on at least one needle in each fascicle. Collection of needles was carried out every 4 weeks for 2 years, beginning in the first week of February 2011 and ending in January 2013, in order to ensure needles and fruit bodies from different seasons and physiological stages were tested. At each of the 26 collection dates (i.e., run replicates) seven fascicles were placed into each of 16 nylon mesh bags (Agralan Enviromesh, bags approx. $18 \times 10 \mathrm{~cm}$, mesh size $2 \times 2 \mathrm{~mm}$, see Fig. 1) and laid out in the 19-year-old stand. Eight of the mesh bags were tied to branches approx. $3.5 \mathrm{~m}$ above the ground (Fig. 1A and B). The remaining bags were laid out approximately $1.5 \mathrm{~m}$ apart in a line on the surface of the litter layer (Fig. 1C and D).

Every 4 weeks, one of the eight mesh bags with suspended needles and one of the eight mesh bags from the litter layer from each needle collection date (i.e., run replicates) were taken back to the laboratory and acervuli assessed for viable D. septosporum propagules. At the same time, a sample of freshly collected infected needles was also assessed. Thus, bagged needles were assessed for viable propagules on the week they were collected (i.e., fresh, at time 0 ), and after 4,8 , $12,16,20,24,28$, and 32 weeks exposure in both positions (the litter or suspended in the branches). Needle assessments were carried out every 4 weeks for 2 years (from February 2011 to August 2013) to determine if survival time of the fungus varied with season and the actual weather conditions the needles were exposed to. Therefore, 26 run replicates were carried out; each run replicate consisted of assessing freshly collected needles as well as needles exposed to each of the eight exposure lengths (see Supplementary Table 1 for timings of needle collections and assessments).

Weather data, in the form of air temperature, rainfall, relative humidity, wind speed, and photosynthetically active radiation (PAR) were collected from a weather station (Delta-T) in the stand from which the needles were collected.

Assessment of viable $D$. septosporum propagules. Three needles from each bag were assessed at each assessment time interval (i.e., needle replicates), with the remainder of the needles placed into gripseal plastic bags and stored at $-70^{\circ} \mathrm{C}$. Three freshly collected needles were also assessed for each collection date (i.e., run replicate).
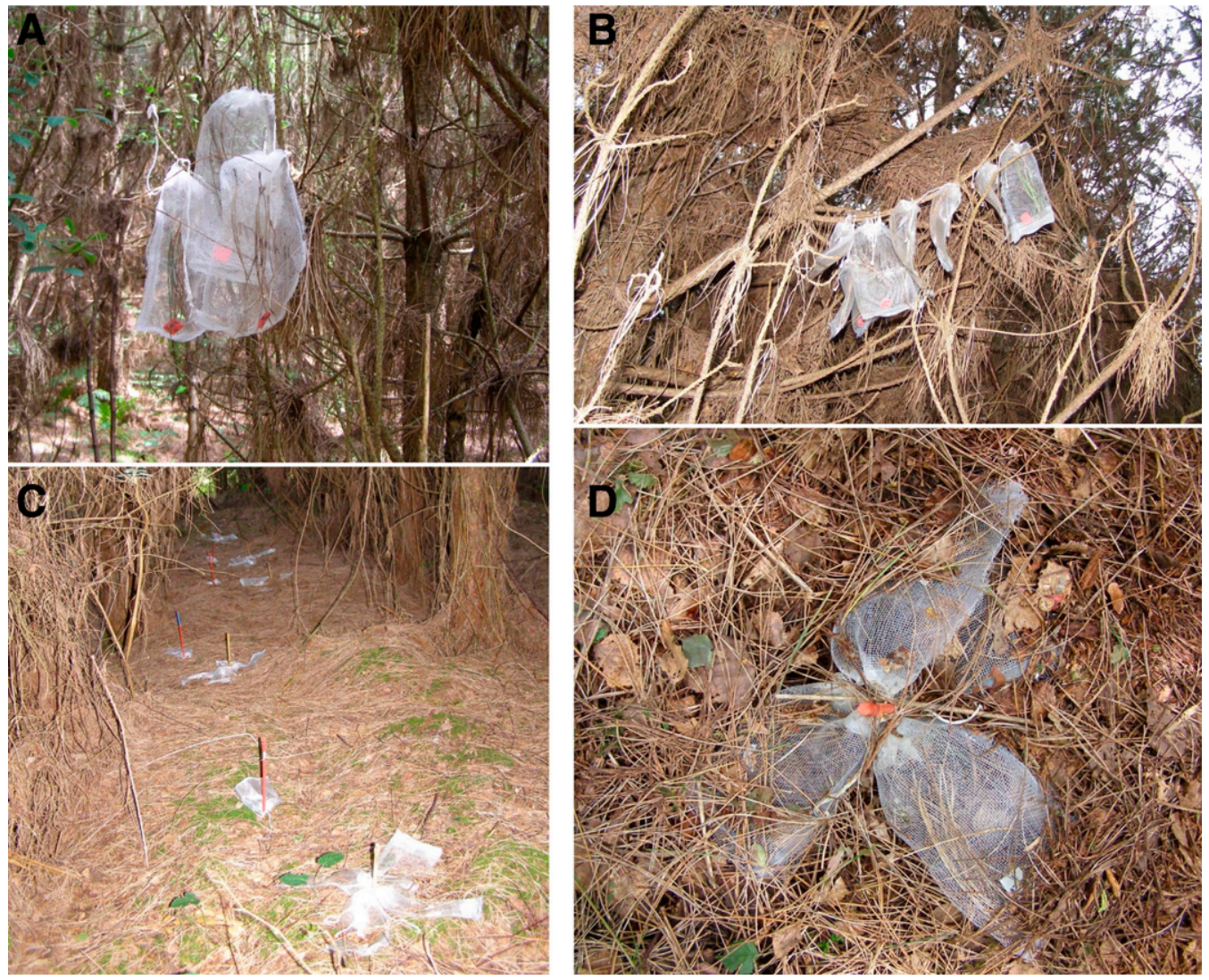

Fig. 1. Persistence trial layout. A and B, Bagged needles suspended in the canopy to simulate shed needles caught among branches. C, Spacing of bagged needles on the forest floor. D, Close up of bagged needles on the forest floor. 
Each needle was wiped with a tissue soaked in industrial methylated spirits (IMS) and an individual acervulus from each needle excised under a dissecting microscope (30x). The excised acervulus was placed in a $2.0 \mathrm{ml}$ microcentrifuge tube (MCT) along with an IMS sterilized and air dried $6 \mathrm{~mm}$ steel ball and $200 \mu \mathrm{l}$ sterile distilled water (SDW). Samples were then ground on a bead mill (Retsch, Haan, Germany) for $2 \mathrm{~min}$ at $30 \mathrm{~Hz}$. This allowed release of all conidia into the water while causing minimal damage to the spores. Some hyphal fragments are also likely to have also been released from the acervulus into the suspension, although they were not observed directly. Two spread cultures, each containing $80 \mu \mathrm{l}$ of the resulting suspension, were made on $90 \mathrm{~mm}$ petri dishes of dothistroma medium (Bradshaw et al. 2000) supplemented with $20 \mathrm{ml}$ of a $1 \%$ streptomycin sulfate salt (Sigma-Aldrich, MI, USA) solution per liter of media.

Spread cultures were incubated in the dark at $20^{\circ} \mathrm{C}$ for 9 days after which the number of $D$. septosporum colonies was counted. D. septosporum colonies from each needle were then subcultured onto dothistroma sporulation medium (Bradshaw et al. 2000) bijou slopes and stored at $-20^{\circ} \mathrm{C}$.

Microsatellite analysis. Microsatellite markers were used to investigate whether particular D. septosporum multilocus haplotypes (MLHs) were more prevalent in abscised needles than other MLHs. Isolates recovered from abscised needles exposed to field conditions for 24, 28, and 32 weeks (termed the 'persistent' group) were compared with the overall population, represented by isolates recovered from freshly collected needles and from those exposed to only 4 weeks of field conditions (termed the 'general population' group). DNA extraction, mating type determination, and microsatellite alleles at 11 loci were determined using the methods detailed in Mullett et al. (2015). Briefly, DNA was extracted from cultures using a Kingfisher Flex magnetic particle processor and Kingfisher Plant DNA Extraction kits (Thermo Scientific, MA, USA). Species-specific mating type primers (Groenewald et al. 2007) and microsatellite markers Doth_DS1, Doth_DS2, Doth_E, Doth_F, Doth_G, Doth_I, Doth_J, Doth_K, Doth_L, Doth_M, and Doth_O (Barnes et al. 2008) were used for multilocus haplotyping.

Statistical methods. Initial viable propagule counts varied greatly across the run replicates of the study, with time series analysis failing to identify any monthly, seasonal, or yearly components that might explain this variation. As the viable propagule counts between individual needle replicates within each run replicate exhibited even greater initial variability, replicate needle and run data were pooled in a first attempt to model persistence rates. Therefore, for an overview of propagule decay patterns in abscised needles, data were pooled for all litter and suspended assessment periods over the two years: i.e., all litter needles from the 4-week exposure period were pooled regardless of the specific month they were exposed, all suspended needles from the 4-week assessment period were pooled, etc... Mean decay rates of D. septosporum propagules were then calculated using a generalized linear model with a Poisson distribution implemented in GENSTAT 14.1 (VSN International 2011). The median lethal time (Lethal Time 50 or $\mathrm{LT}_{50}$ ) was calculated from the model. This is the median time required for half of the propagules to become nonviable. The time needed for $90 \%$ of the propagules to become nonviable, the $\mathrm{LT}_{90}$ value, was also calculated as these are potentially more informative for forest management purposes.

To investigate the influence of particular weather conditions on decay rates, a multiplicative model was fitted to the data to test for the effect of assessment week and exposure time. The model was:

Number of viable propagules ${ }_{t}=$ number of viable propagules t-1 $_{1} \times \alpha\left(\right.$ week $\left._{t}\right) \times \beta\left(\right.$ time $\left._{j}\right)$

Where $t=$ the time of assessment of propagule viability, in 4-week increments; $\alpha=$ a parameter for the effect of week $t$, the week of the year the assessment was carried out; and $\beta=$ a parameter for the effect of time $j$, the number of 4 -week exposure periods that the needles were out in the field. The term $\log$ (number of viable propagules at time $t-1$ ) was set as an offset in the model.
A series of regression models were fitted to identify relationships between the resulting parameter estimates for every assessment period $(t)$ and meteorological metrics recorded during the preceding 4-week period. The meteorological metrics were a summary of the weather the needles had been exposed to during the 4-week period before they were assessed. The metrics were composed of mean temperature, mean windspeed, mean relative humidity, mean PAR (photosynthetically active radiation), and total precipitation over the 28 days prior to assessment.

Molecular statistical methods. Mating type and 11 microsatellite markers were used to assign isolates an MLH. Isolates with the same allele at all 12 loci were considered the same MLH (i.e., a clone). Two methods were used to compare the persistent and general population groups. Firstly, an AMOVA was conducted in GENALEX 6.5 (Peakall and Smouse 2012) to investigate if the two groups were significantly differentiated. Secondly, the $\chi^{2}$ value of the contingency table with the counts of each MLH was calculated. $\chi^{2}$ values are unreliable when expected frequencies are low (i.e., $<1$, or $\leq 20 \%$ of values $<5$ ) as is often the case for genotype or multilocus haplotype data (Cochran 1954; Roff and Bentzen 1989), and many infrequent MLHs were observed in the dataset. Therefore, a distribution of $\chi^{2}$ values, if the null hypothesis of no differentiation was true, was generated using the Monte Carlo method as suggested by Roff and Bentzen (1989), and compared with the $\chi^{2}$ value of the original dataset. The number of times the $\chi^{2}$ value of the randomized datasets equaled or exceeded that of the original dataset allowed calculation of the probability of the null hypothesis being true. The method was implemented in the CHIRXC program using 1,000 simulations (Zaykin and Pudovkin 1993). Additionally, indices of genetic variation were calculated using methods outlined in Mullett et al. (2015). Briefly, haplotypic diversity was calculated using MULTILOCUS 1.3b (Agapow and Burt 2001), gene diversity using ARLEQUIN 3.5 (Excoffier and Lischer 2010), allelic richness and private allele richness using ADZE (Szpiech et al. 2008), and clonal fraction using the method of Zhan et al. (2003).

\section{Results}

Decay of $D$. septosporum propagules and median lethal times. Viable D. septosporum propagules could still be detected in needles exposed for 32 weeks in the field (the maximum time of exposure), although only at very low levels. For needles placed in the litter layer, fewer than $4 \%$ of all needles assessed harbored viable $D$. septosporum after 32 weeks, while for suspended needles, $16 \%$ harbored viable propagules after the same time. However, in almost all cases this was limited to one or two viable $D$. septosporum propagules per needle (i.e., per acervulus).

The number of viable propagules declined rapidly with increasing time of exposure in both litter and suspended needle samples (Fig. 2). For the analysis all assessment times and 4-week exposure periods were combined, giving a mean decay rate of 0.42 for the number of viable propagules in acervuli for the litter needles and 0.61 for the suspended needles (Table 1). The two decay rates were significantly different $\left(\mathrm{F}_{1,482}=30.8, P<0.001\right)$ with propagules from litter needles declining at a faster rate.

The $95 \%$ confidence interval for the litter needles' $\mathrm{LT}_{50}$ was 20 to 28 days (i.e., 0.7 to 1.0 of a 4 -week period), while the $95 \%$ confidence interval for the suspended needles' $\mathrm{LT}_{50}$ was 34 to 48 days (i.e., 1.2 to 1.74 -week periods). For the litter and suspended needles' $\mathrm{LT}_{90}$, the $95 \%$ confidence interval was 63 to 90 days (i.e., 2.25 to 3.2 4-week periods), and 113 to 157 days (i.e., 4.05 to 5.64 -week periods), respectively. This is equivalent to the number of viable D. septosporum propagules reducing 56 to $59 \%$ faster when infected needles were in the litter layer compared with suspended in the tree canopy.

Correlations with weather variables. The regression analysis between the parameter estimates for each 4-week assessment period $(t)$ and the meteorological metrics revealed a significant negative effect of humidity $(P<0.01)$ on the viability of $D$. septosporum propagules in suspended needles. Lower humidity levels were therefore associated with higher propagule survival in the suspended 
needles. However, none of the meteorological variables were found to have a significant effect on the viability of $D$. septosporum in the litter needles.

Microsatellite analysis. The AMOVA did not support any significant population differentiation (d.f. $=1, P=0.820$ ), and the analysis of the contingency table and its randomizations confirmed the null hypothesis of no difference between the two groups (general population group versus persistent group) $\left(\chi^{2}=60.3095\right.$, d.f. $=63$; $P$-value $=0.634$ [95\% confidence interval 0.604 to 0.664$]$ ). Therefore, both tests endorsed the lack of any distinctive population or MLHs persisting on needles. All groupings of the data had similar levels of haplotypic and gene diversity, as well as comparable clonal fractions (Table 2), further supporting the lack of a distinct population grouping of haplotypes able to persist in needles for extended periods.

\section{Discussion}

Abscised needles are clearly not the ideal habitat for $D$. septosporum over a period of several months. Survival declined rapidly once needles were shed from the tree. Although a higher number of infective propagules were recovered from needles suspended above the forest floor compared with needles in the litter, for both the number of viable propagules was halved one to two months after abscission and dropped to $10 \%$ within six months. Thus, shed needles contribute only slightly to the overall inoculum load in the stand with still attached needles contributing the majority of inoculum. Furthermore, isolates from the 'persistent population' were not differentiated genetically from the general population of isolates.

Many aspects, ranging from environmental conditions to microarthropod communities, differ in the tree canopy when compared with the forest floor. The canopy is subject to more extreme climatic conditions with greater exposure to wind, sunlight, and more frequent and extreme wet/dry cycles (Lindo and Winchester 2006). Relative humidity is also lower in the canopy and decreases with increasing canopy height (Cardelús and Chazdon 2005; Unterseher and Tal 2006). The reverse is true of temperature during the day, with higher temperatures occurring in the canopy (Bohlman et al. 1995), and microarthropods such as mites and collembolans are more numerous on the forest floor than in the canopy (Lindo and Winchester 2006, 2007). These conditions all affect the rate of microbial colonization and activity.
Microarthropods are known to eat fungi, in some cases selectively feeding on particular fungal species (Mitchell and Parkinson 1976; Parkinson et al. 1979) and such selective feeding can alter the composition of the microbial community (Mitchell and Parkinson 1976). In this study, microarthropods were not observed systematically, yet casual observations indicated more microarthropods in the older litter needles with many $D$. septosporum fruit bodies 'missing,' as evidenced by blackened depressions with rough edges within the red bands when observed under a dissecting microscope. Presumably the fruit bodies were being consumed by microarthropods and it may be that D. septosporum is a particularly palatable, or just a highly concentrated, food source. Some arthropods are good dispersers of propagules (both fungal and bacterial) both in their feces and on their bodies, potentially leading to higher rates of microbial colonization where they are numerous (Coulis et al. 2013; Lilleskov and Bruns 2005). Furthermore, Kaneko et al. (1998) and Setälä et al. (1988) reported higher levels of microbial activity from litter with increased levels of microarthropods.

The different climatic conditions in the canopy have a strong effect on the microbial community. While solar radiation, particularly UV radiation, is known to kill fungal spores, $D$. septosporum conidia are likely to be well protected inside an acervulus, as has been shown for other fungi (Rotem and Aust 1991), yet any competing colonizing fungal spores on the surface would be slightly more exposed to radiation, potentially slowing their colonization of the needles. However, the higher solar radiation and greater exposure to wind in the canopy also leads to increased drying. Many studies have reported that moisture is a key factor influencing microbial activity in plant litter (Butenschoen et al. 2011; Lee et al. 2014; Riutta et al. 2012; Schimel et al. 1999; Witkamp 1966; Zelles et al. 1991). Higher microbial activity is known to result in faster breakdown

Table 1. Parameter estimates from the generalized linear model of D. septosporum propagule decay

\begin{tabular}{lccrcc}
\hline Parameter & Estimate & $\begin{array}{c}\text { Standard } \\
\text { error }\end{array}$ & $\mathbf{t}(\mathbf{4 8 2})$ & t. pr. & $\begin{array}{c}\text { Antilog of } \\
\text { estimate }\end{array}$ \\
\hline Constant & 5.5219 & 0.0849 & 65.07 & $<0.001$ & 250.1 \\
Litter & -0.8695 & 0.0778 & -11.18 & $<0.001$ & 0.4191 \\
Suspended & -0.4877 & 0.0405 & -12.05 & $<0.001$ & 0.6140 \\
\hline
\end{tabular}

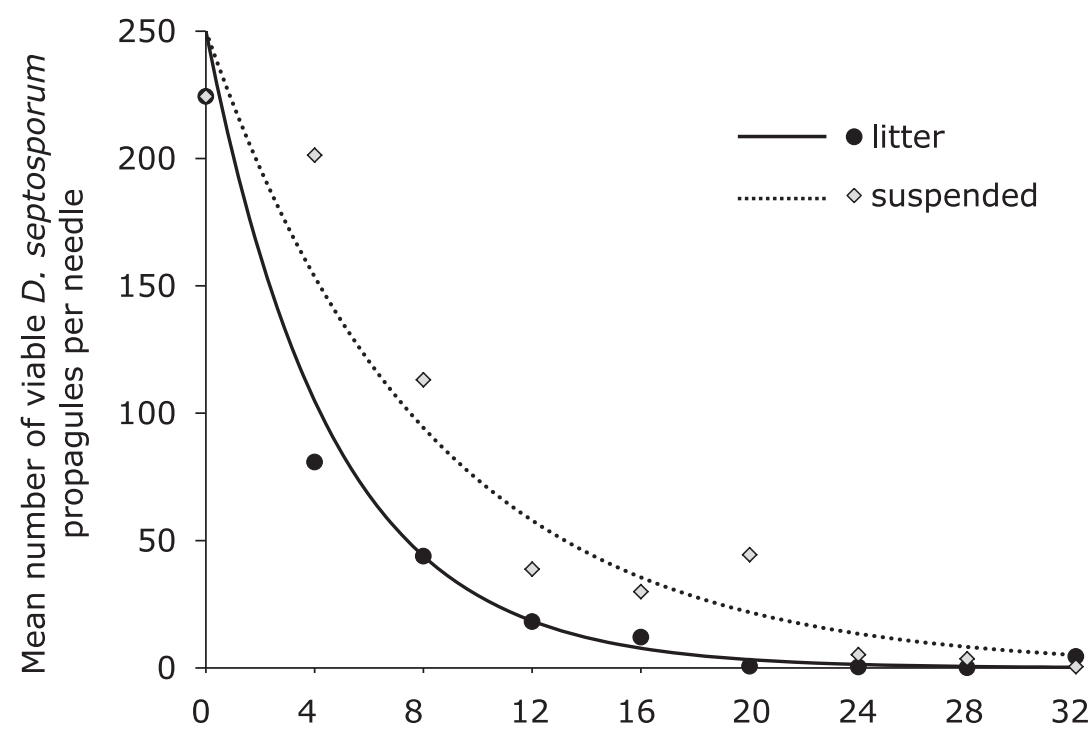

Number of weeks exposure in field

Fig. 2. Mean number of viable $D$. septosporum propagules recovered from litter needles and suspended needles in 4-week exposure periods in the field. Fitted lines are estimated values from the generalized linear model of mean propagule numbers from pooled data ( $n=26$ for each position). 
and decomposition of the shed plant material (Witkamp 1963, 1966). Baldrian et al. (2010) reported that microbial biomass increases with litter moisture and that fungi were more affected by moisture than were bacteria. Additionally, it has been suggested that the stress effect of repeatedly wetting and drying the canopy litter has a negative effect on microbial activity (Bohlman et al. 1995; Schimel et al. 1999). The combined effect of these factors generally results in lower microbial activity and thus reduced rates of decomposition in the canopy litter than in the forest floor litter (Cardelús 2010; Li et al. 2014). The lower microbial activity means less competition against D. septosporum for needle resources, allowing the fungus to persist for longer in the canopy than in the forest floor litter. The significant negative effect of relative humidity on persistence of $D$. septosporum in the canopy emphasizes the importance of moisture on microbial activity. In contrast, the forest floor litter layer rarely dried out, thereby sustaining high levels of microbial activity and rapid degradation of D. septosporum. Thus the decay was so rapid in the continuously damp forest floor litter needles that relative humidity played no significant role here. High relative humidity and moisture may also promote D. septosporum conidial release, allowing loss of propagules to the wider environment.

D. septosporum has been considered a weak saprophyte, easily outcompeted on dead needles by saprophytic fungi (Gadgil 1970; Gibson et al. 1964; Shishkina and Tsanava 1966). Shishkina and Tsanava (1966) noted that D. septosporum was quickly overrun by Lophodermium on fallen P. brutia var. pityusa needles in Georgia, while Gibson et al. (1964) reported the rapid decline in the proportion of D. septosporum conidia in litter needles when compared with those of saprophytes, in particular Pestalotiopsis spp. The results of this study are in agreement with these authors. Schwelm et al. (2009) demonstrated that dothistromin, the toxin produced by D. septosporum, is not needed for infection of pine needles by the fungus but it did confer a competitive advantage against other pine needle fungi in vitro. This suggests that even with live host material, the fungus is an inherently weak competitor and dothistromin may be needed to help exclude other fungi. It may not be surprising, therefore, that on dead and dying host material, the fungus is quickly outcompeted by saprophytic organisms better adapted to utilizing dead host material. Needles falling onto the forest floor will be in direct contact with previously shed needles that are already colonized by saprophytes, thereby facilitating the colonization of newly arrived needles by saprophytes. Conversely, in the canopy, needles are often not in direct contact with many other older needles, slowing rate of colonization by saprophytes.

Regardless of the vertical position of the abscised needles in the forest stand, persistence of the fungus is limited. Some fungal propagules are thought to survive over 25 years, although evidence is often anecdotal, e.g., Urocystis cepulae and Synchytrium endobiotium (Putnam and Sindermann 1994; Thaxter 1890). Other fungal propagules can enter a dormancy phase, much like plant seeds, enabling them to survive periods of many years (Bruns et al. 2009; Nara 2009).

A detailed study of $D$. septosporum persistence in fallen needles was also undertaken by Gadgil (1970). He assessed needles in the litter and canopy of both thinned and unthinned $P$. radiata stands in New Zealand and also found a rapid decrease in inoculum, with slightly higher persistence in canopy needles compared with needles on the forest floor. Gadgil (1970) found no viable conidia after 6 months, with the maximal survival time being between 4 and
6 months (i.e., viable at 4 months but not at 6 months, the subsequent assessment period). This result is in broad agreement with the current study although the pathogen was still found to be viable at 6 months in some cases in our study. The difference may be due to a different host species ( $P$. radiata), location and climate (New Zealand), and/ or assessment method. Gadgil (1970) damp-chamber incubated needles recovered from the field and then picked off any exuded conidia with a loop and streaked them onto agar plates. This method allowed assessment of conidia only, but also possibly omitted conidia that might have been released with further incubation. The method used in the current study allowed recovery of all infective propagules in a fruit body regardless of whether these were conidia or mycelial fragments. Both are known to cause infection; in fact, germinating mycelial fragments have been reported to penetrate the host cuticle directly while germinating conidia must enter the needle via stomata (Gadgil 1967). Although potentially more infective, mycelial fragments have not been shown to be dispersed along with conidia; therefore, the current study may slightly overestimate the quantity of easily dispersible inoculum. In Japan, Ito et al. (1975) reported viable $D$. septosporum conidia from abscised $P$. thunbergii and $P$. densiflora needles after 6 months of outdoor winter storage, whereas Shishkina and Tsanava (1966) reported conidia viability as between 3 and 5 months from $P$. brutia var. pityusa needles stored as herbarium specimens. Gibson et al. (1964) also recovered viable conidia from $P$. radiata foliage that was kept in a dry incubator at $30^{\circ} \mathrm{C}$ for 5 months. They also found live conidia on foliage kept at room temperature for 11 months, the maximum reported in the literature (Gibson et al. 1964).

Investigation using microsatellite markers did not reveal any particular MLHs that were associated with longer persistence in abscised needles. This is consistent with the view that D. septosporum has limited survival on abscised needles, so any selection pressures are likely to be acting much earlier in the pathogen's life cycle, before needles are shed. It would seem that persistence of the fungus is governed primarily by the environmental conditions the abscised needles are subjected to with particular MLHs being of little consequence in this respect. It is likely that needles harboring the fungus many months after abscission were subjected to lower moisture levels, slower colonization by saprophytes, lower levels of microbial activity and degradation, and that the D. septosporum fruit body escaped microarthropod predation.

In conclusion, shed needles infected with $D$. septosporum contribute only slightly, and for a limited time, to the overall pathogen inoculum levels in a stand. Replanting a felled infected area with a susceptible pine species carries risks, but where this is to be undertaken, any inoculum in the litter will be reduced by $90 \%$ after 3 months. If replanting is undertaken after 6 or 12 months, inoculum from the site is likely to be negligible, although not absent. Adjacent infected stands are likely to pose a much greater risk. Although shed needles caught in the canopy of a standing forest can be a threat for slightly longer than those reaching the forest floor, inoculum levels were also found to decrease rapidly in this environment, halving in under 2 months. However, to minimize the number of needles caught in the canopy and thus reduce the inoculum they will subsequently contribute, it is recommended that thinning, pruning, and brashing operations are carried out prior to the main needle shedding periods of late summer and autumn.

Table 2. Summary of isolate numbers and genetic variability of D. septosporum used in this study ${ }^{\mathrm{a}}$

\begin{tabular}{lccccccc}
\hline Group & $\begin{array}{c}\text { Number of } \\
\text { isolates }\end{array}$ & $\begin{array}{c}\text { Number of different } \\
\text { multilocus haplotypes }\end{array}$ & $\begin{array}{c}\text { Haplotypic } \\
\text { diversity }\end{array}$ & $\begin{array}{c}\text { Clonal } \\
\text { fraction }\end{array}$ & $\begin{array}{c}\text { Gene } \\
\text { Diversity }\end{array}$ & $\begin{array}{c}\mathbf{A}_{\mathbf{R}} \pm \text { standard } \\
\text { error }\end{array}$ & $\begin{array}{c}\mathbf{P A}_{\mathbf{R}} \pm \text { standard } \\
\text { error }\end{array}$ \\
\hline All isolates & 241 & 64 & 0.942 & 0.734 & 0.542 & n.a. & n.a. \\
$\begin{array}{l}\text { Fresh needle } \\
\text { isolates }\end{array}$ & 179 & 54 & 0.939 & 0.698 & 0.546 & $4.472 \pm 0.606$ & $0.571 \pm 0.007$ \\
\begin{tabular}{l} 
Persistent isolates \\
\hline
\end{tabular} & 62 & 27 & 0.950 & 0.565 & 0.512 & $4.364 \pm 0.560$ & $0.463 \pm 0.124$ \\
\hline
\end{tabular}

${ }^{a}$ Haplotypic diversity calculated using the non-clone-corrected dataset. Gene diversity, allelic richness $\left(A_{R}\right)$, and private allele richness $\left(P A_{R}\right)$ calculated using the clone-corrected dataset. $A_{R}$ and $P A_{R}$ were standardized to the smallest clone-corrected sample size of 27 . 


\section{Acknowledgments}

We thank the Forestry Commission for funding this study. We also thank Joan Webber, Kath Tubby, and two anonymous reviewers whose comments greatly improved the manuscript.

\section{Literature Cited}

Agapow, P.-M., and Burt, A. 2001. Indices of multilocus linkage disequilibrium. Mol. Ecol. Notes 1:101-102.

Baldrian, P., Merhautová, V., Petránková, M., Cajthaml, T., and Šnajdr, J. 2010. Distribution of microbial biomass and activity of extracellular enzymes in a hardwood forest soil reflect soil moisture content. Appl. Soil Ecol. 46: 177-182.

Barnes, I., Cortinas, M. N., Wingfield, M. J., and Wingfield, B. D. 2008. Microsatellite markers for the red band needle blight pathogen, Dothistroma septosporum. Mol. Ecol. Resour. 8:1026-1029.

Bohlman, S., Matelson, T., and Nadkarni, N. 1995. Moisture and temperature patterns of canopy humus and forest floor soil of a montane cloud forest, Costa Rica. Biotropica 27:13-19.

Bond, D. A., and Pope, M. 1980. Ascochyta fabae on winter beans (Vicia faba): pathogen spread and variation in host resistance. Plant Pathol. 29:59-65.

Bradshaw, R. E., Ganley, R. J., Jones, W. T., and Dyer, P. S. 2000. High levels of dothistromin toxin produced by the forest pathogen Dothistroma pini. Mycol. Res. 104:325-332.

Bretag, T. W., Keane, P. J., and Price, T. V. 2006. The epidemiology and control of ascochyta blight in field peas: a review. Aust. J. Agric. Res. 57:883-902.

Brown, A. V., and Webber, J. 2008. Red band needle blight of conifers in Britain. Research Note. Forestry Commission, England.

Bruns, T. D., Peay, K. G., Boynton, P. J., Grubisha, L. C., Hynson, N. A., Nguyen, N. H., and Rosenstock, N. P. 2009. Inoculum potential of Rhizopogon spores increases with time over the first $4 \mathrm{yr}$ of a $99-\mathrm{yr}$ spore burial experiment. New Phytol. 181:463-470.

Butenschoen, O., Scheu, S., and Eisenhauer, N. 2011. Interactive effects of warming, soil humidity and plant diversity on litter decomposition and microbial activity. Soil Biol. Biochem. 43:1902-1907.

Cardelús, C. L. 2010. Litter decomposition within the canopy and forest floor of three tree species in a tropical lowland rain forest, Costa Rica. Biotropica 42: 300-308.

Cardelús, C. L., and Chazdon, R. L. 2005. Inner-crown microenvironments of two emergent tree species in a lowland wet forest. Biotropica 37:238-244.

Carter, M., and Moller, W. 1961. Factors affecting the survival and dissemination of Mycosphaerella pinodes (Berk \& Blox) vestergr. in South Australian irrigated pea fields. Aust. J. Agric. Res. 12:878-888.

Cochran, W. G. 1954. Some methods for strengthening the common x2 tests. Biometrics 10:417-451.

Coulis, M., Hättenschwiler, S., Fromin, N., and David, J. F. 2013. Macroarthropodmicroorganism interactions during the decomposition of Mediterranean shrub litter at different moisture levels. Soil Biol. Biochem. 64:114-121.

Davidson, J. A., and Kimber, R. B. E. 2007. Integrated disease management of ascochyta blight in pulse crops. Pages 99-110 in: Ascochyta blights of grain legumes. B. Tivoli, A. Baranger, F. J. Muehlbauer, and B. M. Cooke, eds. Springer, Dordrecht, The Netherlands.

Diwani, S. A., and Millar, C. S. 1990. Sources of inoculum of Lophodermium seditiosum on Pinus sylvestris. Eur. J. Forest Pathol. 20:1-7.

Excoffier, L., and Lischer, H. E. L. 2010. ARLEQUIN suite ver 3.5: a new series of programs to perform population genetics analyses under Linux and Windows. Mol. Ecol. Resour. 10:564-567.

Gadgil, P. D. 1967. Infection of Pinus radiata needles by Dothistroma pini. N.Z. J. Bot. 5:498-503.

Gadgil, P. D. 1970. Survival of Dothistroma pini on fallen needles of Pinus radiata. N.Z. J. Bot. 8:303-309.

Gibson, I. A. S. 1972. Dothistroma blight of Pinus radiata. Annu. Rev. Phytopathol. 10:51-72.

Gibson, I., Christensen, P. S., and Munga, F. M. 1964. First observations in Kenya of a foliage disease of pines caused by Dothistroma pini Hulbary. Commonw. For. Rev. 43:31-48.

Gilmour, J. W. 1967. Distribution, impact and control of Dothistroma pini in New Zealand. Reprint. New Zealand Forest Service, Rotorua, New Zealand.

Gladieux, P., Zhang, X.-G., Afoufa-Bastien, D., Valdebenito Sanhueza, R.-M., Sbaghi, M., and Le Cam, B. 2008. On the origin and spread of the scab disease of apple: out of Central Asia ed. Christophe d'Enfert. PLoS One 3: e1455.

Groenewald, M., Barnes, I., Bradshaw, R. E., Brown, A. V., Dale, A., Groenewald, J. Z., Lewis, K. J., Wingfield, B. D., Wingfield, M. J., and Crous, P. W. 2007. Characterization and distribution of mating type genes in the Dothistroma needle blight pathogens. Phytopathology 97:825-834.

Hawthorne, W. A., Bretag, T., Raynes, M., Davidson, J. A., Kimber, R. B. E., Nikandrow, A., Matthews, P., and Paull, J. G. 2004. Faba bean disease management strategy for southern region GRDC 2004. Pulse Australia, Sydney.

Holb, I. J. 2006. Effect of six sanitation treatments on leaf litter density, ascospore production of Venturia inaequalis and scab incidence in integrated and organic apple orchards. Eur. J. Plant Pathol. 115:293-307.
Ito, K., Zinno, Y., and Suto, Y. 1975. Dothistroma needle blight of pines in Japan. Bull. Gov. For. Exp. Stn. Tokyo 272:123-140.

Kaneko, N., McLean, M. A., and Parkinson, D. 1998. Do mites and Collembola affect pine litter fungal biomass and microbial respiration? Appl. Soil Ecol. 9:209-213.

Karadžič, D. M. 1989. Scirrhia pini Funk et Parker. Life cycle of the fungus in plantations of Pinus nigra Arn. in Serbia. Eur. J. Forest Pathol. 19:231-236.

Lee, H., Fitzgerald, J., Hewins, D. B., McCulley, R. L., Archer, S. R., Rahn, T., and Throop, H. L. 2014. Soil moisture and soil-litter mixing effects on surface litter decomposition: A controlled environment assessment. Soil Biol. Biochem. 72: 123-132.

Li, S., Liu, W.-Y., Li, D.-W., Li, Z.-X., Song, L., Chen, K., and Fu, Y. 2014 Slower rates of litter decomposition of dominant epiphytes in the canopy than on the forest floor in a subtropical montane forest, southwest China. Soil Biol. Biochem. 70:211-220.

Lilleskov, E. A., and Bruns, T. D. 2005. Spore dispersal of a resupinate ectomycorrhizal fungus, Tomentella sublilacina, via soil food webs. Mycologia 97:762-769.

Lindo, Z., and Winchester, N. N. 2006. A comparison of microarthropod assemblages with emphasis on oribatid mites in canopy suspended soils and forest floors associated with ancient western redcedar trees. Pedobiologia (Jena) 50:31-41.

Lindo, Z., and Winchester, N. N. 2007. Oribatid mite communities and foliar litter decomposition in canopy suspended soils and forest floor habitats of western redcedar forests, Vancouver Island, Canada. Soil Biol. Biochem. 39:2957-2966.

MacHardy, W. E. 1996. Apple Scab: Biology, Epidemiology, and Management APS Press, St. Paul, MN.

Mitchell, M. J., and Parkinson, D. 1976. Fungal feeding or Oribatid mites (Acari: Cryptostigmata) in an aspen woodland soil. Ecology 57:302-312.

Morrall, R. A. A. 1997. Evolution of lentil diseases over 25 years in western Canada. Can. J. Plant Pathol. 19:197-207.

Mullett, M. S. 2014. The Epidemiology of Dothistroma Needle Blight in Britain. $\mathrm{Ph} . \mathrm{D}$. Thesis, Imperial College, London.

Mullett, M. S., Brown, A. V., and Barnes, I. 2015. Population structure and reproductive mode of Dothistroma septosporum in the Brittany peninsula of France. Eur. J. Plant Pathol. 143:261-275.

Nara, K. 2009. Spores of ectomycorrhizal fungi: ecological strategies for germination and dormancy. New Phytol. 181:245-248.

Parkinson, D., Visser, S., and Whittaker, J. B. 1979. Effects of collembolan grazing on fungal colonization of leaf litter. Soil Biol. Biochem. 11:529-535.

Peakall, R., and Smouse, P. E. 2012. GenAlEx 6.5: genetic analysis in Excel. Population genetic software for teaching and research-an update. Bioinformatics 28:2537-2539.

Peterson, G. W. 1967. Dothistroma needle blight of Austrian and ponderosa pines: epidemiology and control. Phytopathology 57:437-441.

Peterson, G. W. 1973. Infection of Austrian and ponderosa pines by Dothistroma pini in Eastern Nebraska. Phytopathology 63:1060-1063.

Putnam, M., and Sindermann, A. 1994. Eradication of potato wart disease from Maryland. Am. Potato J. 71:743-747.

Riutta, T., Slade, E. M., Bebber, D. P., Taylor, M. E., Malhi, Y., Riordan, P., et al. 2012. Experimental evidence for the interacting effects of forest edge, moisture and soil macrofauna on leaf litter decomposition. Soil Biol. Biochem. 49:124-131.

Roff, D. A., and Bentzen, P. 1989. The statistical analysis of mitochondrial DNA polymorphisms: chi 2 and the problem of small samples. Mol. Biol. Evol. 6: 539-545.

Rogerson, C. T. 1953. Kansas mycological notes: 1951. Trans. Kans. Acad. Sci. 1903-. 56:53-57.

Rotem, J., and Aust, H. J. 1991. The effect of ultraviolet and solar radiation and temperature on survival of fungal propagules. J. Phytopathol. 133:76-84.

Schimel, J. P., Gulledge, J. M., Clein-Curley, J. S., Lindstrom, J. E., and Braddock, J. F. 1999. Moisture effects on microbial activity and community structure in decomposing birch litter in the Alaskan taiga. Soil Biol. Biochem. 31:831-838.

Schwelm, A., Barron, N. J., Baker, J., Dick, M., Long, P. G., Zhang, S., and Bradshaw, R. E. 2009. Dothistromin toxin is not required for dothistroma needle blight in Pinus radiata. Plant Pathol. 58:293-304.

Setälä, H., Haimi, J., and Huhta, V. 1988. A microcosm study on the respiration and weight loss in birch litter and raw humus as influenced by soil fauna. Biol. Fertil. Soils 5:282-287.

Shishkina, A. K., and Tsanava, N. I. 1966. изучению красной пятнистости на хвое сосны в Грузии. [On studying red spot of pine needles in Georgia] Proc. Georgian Inst. Plant Protect. 18:289-295.

Strouts, R. G., and Winter, T. G. 2000. Diagnosis of Ill Health in Trees Arboricultural Association, Romsey, UK.

Szpiech, Z. A., Jakobsson, M., and Rosenberg, N. A. 2008. ADZE: a rarefaction approach for counting alleles private to combinations of populations. Bioinformatics 24:2498-2504.

Thaxter, R. 1890. The smut of onions (Urocystis cepulae Frost). Conn. Agric. Exp. Stn. Annu. Rep. 1890:127-154.

Unterseher, M., and Tal, O. 2006. Influence of small scale conditions on the diversity of wood decay fungi in a temperate, mixed deciduous forest canopy. Mycol. Res. 110:169-178.

VSN International. 2011. GenStat for Windows, 14th Ed. VSN International, Hemel Hempstead, UK. 
Watt, M. S., Kriticos, D. J., Alcaraz, S., Brown, A. V., and Leriche, A. 2009. The hosts and potential geographic range of Dothistroma needle blight. For. Ecol. Manage. 257:1505-1519.

Witkamp, M. 1963. Microbial populations of leaf litter in relation to environmental conditions and decomposition. Ecology 44:370-377.

Witkamp, M. 1966. Decomposition of leaf litter in relation to environment, microflora, and microbial respiration. Ecology 47:194-201.

Xu, X., Harvey, N., Roberts, A., and Barbara, D. 2012. Population variation of apple scab (Venturia inaequalis) within mixed orchards in the UK. Eur. J. Plant Pathol. 135:97-104.
Zaykin, D. V., and Pudovkin, A. I. 1993. Two programs to estimate significance of $\mathrm{x} 2$ values using pseudo-probability tests. J. Hered. 84:152.

Zelles, L., Adrian, P., Bai, Q. Y., Stepper, K., Adrian, M. V., Fischer, K., Maier, A., and Ziegler, A. 1991. Microbial activity measured in soils stored under different temperature and humidity conditions. Soil Biol. Biochem. 23: 955-962.

Zhan, J., Pettway, R. E., and McDonald, B. A. 2003. The global genetic structure of the wheat pathogen Mycosphaerella graminicola is characterized by high nuclear diversity, low mitochondrial diversity, regular recombination, and gene flow. Fungal Genet. Biol. 38:286-297. 